DOI:10.17951/h.2019.53.4.69-90

\begin{tabular}{lcc}
\hline & A N N A L E S \\
UNIVERSITATIS MARIAE CURIE-SKŁODOWSKA \\
LUBLIN - POLONIA \\
SOL. LIII, 4 & SECTIO H \\
\hline
\end{tabular}

KATARZYNA KOCHANIAK

katarzyna.kochaniak@uek.krakow.pl

Uniwersytet Ekonomiczny w Krakowie. Kolegium Ekonomii, Finansów i Prawa

ul. Rakowicka 27, 31-510 Kraków, Polska

ORCID ID: https://orcid.org/0000-0002-0680-9922

\title{
Kredyty dla gospodarstw domowych strefy euro w okresie restrykcyjnej polityki kredytowej banków i niestandardowych działań Eurosystemu
}

Loans to Euro Area Households in the Period of Restrictive Lending Policy of Banks and Non-standard Eurosystem Activities

Keywords: loans to households; ECB monetary policy; Eurozone

Słowa kluczowe: kredyty dla gospodarstw domowych; polityka pieniężna EBC; strefa euro JEL: G01; G21; G28

Propozycja cytowania: Kochaniak, K. (2019). Kredyty dla gospodarstw domowych strefy euro w okresie restrykcyjnej polityki kredytowej banków i niestandardowych działań Eurosystemu. Annales Universitatis Mariae Curie-Skłodowska, sectio H-Oeconomia, Vol. 53, No. 4.

\footnotetext{
Abstract

Theoretical background: The article presents the problem of the diversity of euro area countries in terms of lending to households by banks, in the context of restrictive lending policy and the non-standard measures taken by the Eurosystem to liberalize it. Limited availability of loans for the non-financial sector and its negative economic effects were the result of the global financial crisis.

Purpose of the article: The aim of the study is to analyze the development of loans to households in the euro area in the period from August 2007 to December 2018. It was important to assess their variability in time and spatial differentiation in two sub-periods - the financial crisis with continuing destabilization financial market and non-standard ECB solutions aimed at reviving banks' lending activities.
} 
Research methods: The study used figures related to the credit institutions' sector receivables and household sector indebtedness for loans in individual euro area countries. The characteristics of local conditions in the area of examined loans were based on selected descriptive statistics, and the taxonomic method was used to identify their similarity.

Main findings: The results of the survey showed significant heterogeneity of the euro area countries in terms of the features of the household loan market in both periods of the survey. However, analyzing the changes taking place showed that their direction was consistent in most Member States.

\begin{abstract}
Abstrakt
Uzasadnienie teoretyczne: W artykule zostal opisany problem zróżnicowania krajów strefy euro pod względem kredytowania gospodarstw domowych przez banki w warunkach restrykcyjnej polityki kredytowej i podejmowania przez Eurosystem niestandardowych działań na rzecz jej liberalizacji. Ograniczona dostępność kredytów dla sektora niefinansowego oraz jej negatywne skutki gospodarcze były pokłosiem globalnego kryzysu finansowego.

Cel artykułu: Analiza kształtowania się kredytów dla gospodarstw domowych w krajach strefy euro w okresie od sierpnia 2007 r. do grudnia 2018 r. Za ważną uznano ocenę ich zmienności w czasie oraz przestrzennego zróżnicowania w dwóch podokresach - kryzysu finansowego z utrzymującą się po nim destabilizacją rynku finansowego oraz niestandardowych rozwiązań EBC, mających na celu ożywienie działalności kredytowej banków.

Metody badawcze: W badaniu wykorzystano dane liczbowe odnoszące się do należności sektorów instytucji kredytowych oraz zadłużenia sektorów gospodarstw domowych z tytułu kredytów w poszczególnych krajach strefy euro. Charakterystykę lokalnych uwarunkowań w zakresie badanych kredytów przeprowadzono na podstawie wybranych statystyk opisowych, a do identyfikacji ich podobieństwa zastosowano metodę taksonomiczną.

Glówne wnioski: Wyniki badania wykazały istotną heterogeniczność krajów strefy euro pod względem cech rynku kredytów dla gospodarstw domowych w obu okresach badania. Analiza zachodzących na nim zmian pozwoliła jednak stwierdzić zgodność ich kierunku w większości państw członkowskich.
\end{abstract}

\title{
Wprowadzenie
}

W okresie kryzysu finansowego i destabilizacji gospodarczej krajów strefy euro skuteczność polityki pieniężnej Europejskiego Banku Centralnego (EBC) była uwarunkowana stosowaniem niestandardowych instrumentów. Podejmowane wówczas działania miały zapewnić płynność instytucjom kredytowym, a od 2014 r. - łagodzić restrykcyjną politykę kredytową tych podmiotów, której skutkiem były problemy gospodarcze krajów. Jej liberalizację, prowadzącą do ujednolicenia dostępności kredytów dla klientów niefinansowych oraz warunków ich udzielania na całym obszarze strefy euro, utrudniała ówczesna segmentacja rynku finansowego, spowodowana problemami sektorów finansów publicznych wybranych krajów. Wyraźne ukierunkowanie aktywności Eurosystemu na powyższy cel stało się widoczne wraz z wprowadzeniem ujemnej stopy procentowej dla operacji depozytowych i rozpoczęciem targeted longer-term refinancing operations (TLTRO) oraz expanded asset purchase programmes (APP).

Celem niniejszego artykułu jest ocena kształtowania się kredytów dla gospodarstw domowych w krajach strefy euro w okresie od sierpnia 2007 r. do grudnia 
2018 r., z uwzględnieniem ich zmienności w czasie oraz przestrzennego zróżnicowania. Należy wyjaśnić, że przyjęty przedział czasowy obejmuje dwa podokresy: utrwalania restrykcyjnej polityki kredytowej w bankach pod wpływem ewoluującego kryzysu finansowego (sierpień 2007 r. - maj 2014 r.) oraz prowadzenia przez EBC niestandardowych działań na rzecz rozwoju rynku kredytów detalicznych strefy euro (czerwiec 2014 r. - grudzień 2018 r.). ${ }^{1}$ Ze względu na heterogeniczność krajów w zakresie cech sektorów instytucji kredytowych i gospodarstw domowych w realizacji celu pracy pomocne były następujące pytania badawcze:

1. Które cechy kredytów dla gospodarstw domowych można uznać za wspólne w zbiorowości krajów strefy euro, a które za występujące lokalnie?

2. Czy zmiany w zakresie kredytowania gospodarstw domowych w krajach strefy euro były zbieżne z oczekiwaniami EBC w okresie prowadzenia niestandardowych działań na rzecz liberalizacji polityki kredytowej?

3. Czy przeciętne zadłużenie z tytułu kredytów i obciążenie nim dochodów do dyspozycji gospodarstw domowych kształtowało się na zbliżonym poziomie w okresie badania w krajach strefy euro?

4. Które z krajów strefy euro cechowały się podobieństwem pod względem kształtowania się kredytów dla gospodarstw domowych w obu podokresach badania?

Opracowanie składa się z następujących części: przeglądu literatury, charakterystyki działań Eurosystemu na rzecz aktywizacji kredytowania klientów niefinansowych, opisu danych i metody badania, charakterystyki kredytów dla gospodarstw domowych w poszczególnych krajach strefy euro, prezentacji wyników grupowania krajów według podobieństwa cech kredytów dla gospodarstw domowych oraz zakończenia.

\section{Przegląd literatury}

Problem wpływu polityki pieniężnej na działalność kredytową banków był w przeszłości przedmiotem wielu badań empirycznych, odnoszących się jednak głównie do jej standardowych instrumentów. Te ukierunkowane na niestandardowe instrumenty są prowadzone przede wszystkim w ostatnich latach pod wpływem doświadczeń Eurosystemu i Systemu Rezerwy Federalnej.

W literaturze znaczenie niestandardowych instrumentów polityki pieniężnej dla dostępności kredytów dla klientów niefinansowych w okresie globalnego kryzysu opisywane jest z uwzględnieniem:

- głównych kanałów transmisji,

\footnotetext{
1 Zaprezentowano wyniki badań wstępnych, przeprowadzonych na potrzeby projektu badawczego dotyczącego zagregowanych i redystrybucyjnych efektów niekonwencjonalnych działań Eurosystemu na rzecz rozwoju kredytowania gospodarstw domowych w strefie euro.
} 
- skuteczności owych instrumentów w oddziaływaniu na skalę i warunki kredytowania (oprocentowanie i okres spłaty), a także trwałości ich wpływu,

- heterogeniczności wpływu niestandardowych instrumentów na akcję kredytową prowadzoną przez banki w poszczególnych krajach strefy euro.

Ponadto wskazuje się na ograniczoną skuteczność standardowych instrumentów polityki pieniężnej w warunkach skrajnych rynku finansowego i stagnacji gospodarczej oraz na konieczność podejmowania niekonwencjonalnych działań przez banki centralne (EBC, 2017a, s. 1-24). Zjawisko neutralizacji wpływu stopy procentowej EBC na kształtowanie poziomu oprocentowania kredytów dla klientów niefinansowych tłumaczono podczas ostatniego kryzysu finansowego m.in. wyższymi kosztami funduszy hurtowych, koniecznością podwyższenia marż przez instytucje kredytowe z powodu nasilonego ryzyka kredytowego czy wzrostem kapitałów na skutek zmian regulacyjnych. Dowodzono przy tym skuteczności oddziaływania niestandardowych instrumentów polityki pieniężnej na politykę kredytową banków m.in. takimi kanałami, jak (EBC, 2017a, s. 6):

1. Bezpośrednie przesyłanie impulsów. Poprawa warunków kredytowania sektora prywatnego była efektem oddziaływania niestandardowych instrumentów na koszt funduszy obcych w bankach. TLTRO pozwalały bowiem dostarczać tym podmiotom długoterminową płynność po niskim koszcie, odpowiadającym oprocentowaniu operacji depozytowych $\mathrm{EBC}$, pod warunkiem ich aktywnego zaangażowania w kredytowanie sektora niefinansowego. Operacje te sprzyjały wzrostowi konkurencji na rynku, któremu towarzyszył spadek marż i oprocentowania kredytów. Z kolei APP umożliwiał bankom sprzedaż asset-backed securities i covered bonds, zwiększając ich zainteresowanie kredytowaniem klientów niefinansowych. Ponieważ koszt finansowania pozyskanego z Eurosystemu był niższy niż hurtowego, możliwe było obniżenie oprocentowania kredytów detalicznych.

2. Równoważenie portfela. Skup obligacji rządowych w ramach APP spowodował obniżenie stopy zwrotu z tych papierów wartościowych, skłaniając banki do większego zaangażowania w aktywa o wyższym zwrocie skorygowanym o ryzyko (np. kredyty).

3. Komunikacja z otoczeniem. Wraz z projekcjami niższego poziomu krótkoterminowych stóp procentowych w przyszłości komunikacja oddziaływała na oczekiwania rynkowe i oprocentowanie kredytów bankowych.

Poważnym problemem w strefie euro było przestrzenne zróżnicowanie oprocentowania kredytów, za które odpowiedzialne były określone czynniki cykliczne i strukturalne (EBC, 2017a, s. 7).

Skłonność banków do kredytowania sektora niefinansowego w warunkach ujemnych stóp procentowych banku centralnego była przedmiotem badań prowadzonych przez Heider, Saidi i Schepens (2018). Autorzy uwzględnili w nich stopień finansowania podmiotów depozytami klientów. Wyniki wykazały, że w podmiotach zależnych od takich depozytów obawa runu prowadziła do utrzymywania ich oprocentowania na poziomie wyższym niż oprocentowanie funduszy rynkowych. 
Akceptacja wyższych kosztów funduszy obcych działała jednak ograniczająco na akcję kredytową i motywowała do inwestowania w aktywa bardziej dochodowe, a tym samym ryzykowne.

Z kolei Gambetti i Musso (2017) analizowali wpływ APP na kredytowanie sektora niefinansowego w strefie euro. Potwierdzili oni znaczenie tego programu dla funkcjonowania kanału kredytowego w krótkim okresie, głównie przez znaczący spadek oprocentowania kredytów, sięgający przeciętnie 5 p.p. w pierwszym roku jego realizacji, a w dalszej kolejności - przez wzrost wolumenu kredytów, którego efekt obserwowany był przede wszystkim w drugim roku po wprowadzeniu programu.

Zmiany w mechanizmie transmisji polityki monetarnej, odnoszące się do kanału kredytowego banków przed kryzysem finansowym oraz w jego trakcie, zostały opisane przez Gambacorta i Marques-Ibanez (2011). Za ważny cel badania autorzy obrali ocenę trwałości identyfikowanych zmian, przypisując im ostatecznie cechę tymczasowości. Wyniki rzuciły nowe światło na funkcjonowanie kanału kredytowego, ponieważ skala wpływu polityki pieniężnej na podaż kredytów w bankach okazała się zależna m.in. od modeli biznesowych tych podmiotów, stopnia wykorzystania krótkoterminowego finansowania, prowadzenia działalności sekurytyzacyjnej, poziomu i jakości kapitałów czy skali dochodów z tytułu opłat. Wyniki potwierdziły możliwość zwiększenia akcji kredytowej w bankach w warunkach niskich stóp procentowych zgodnie z hipotezą „kanału podejmowania ryzyka”. Uznano, że niestandardowe środki miały pozytywny wpływ na kredytowanie, głównie przez oddziaływanie na spready stóp procentowych. W wypadku czynników warunkujących siłę transmisji impulsów polityki pieniężnej w przyszłości autorzy zwrócili uwagę na znaczenie sekurytyzacji, regulacji prawnych (w tym objęcie nimi nowych grup kredytodawców), innowacji finansowych, modeli biznesowych banków, sposobu sprawowania nadzoru oraz gromadzenia danych przez banki centralne.

Black i Rosen (2016) badali wpływ polityki pieniężnej na kredytowanie sektora niefinansowego przez banki w USA, w tym na okres spłaty i skalę tego zaangażowania. Potwierdzili oni praktykę wydłużania okresu spłaty dla nowych kredytów w okresie luzowania ilościowego. Ponadto uzyskane wyniki świadczą o wzroście podaży kredytów w warunkach niższej rzeczywistej stopy funduszy federalnych, zarówno w małych, jak i dużych bankach.

Opisane wyniki dowodzą zasadności prowadzenia badań w obszarze wpływu niestandardowych działań banków centralnych na politykę kredytową banków. W przypadku strefy euro kluczową kwestią pozostaje jednak jego siła ze względu na wielowymiarowe zróżnicowanie krajów objętych wspólną polityką pieniężną. Problem ten dotyczy oddziaływania na poszczególne sektory instytucji kredytowych oraz sektory gospodarstw domowych.

W literaturze brakuje wyników badań ukierunkowanych na pomiar skutków stosowania przez EBC niestandardowych instrumentów dla kształtowania rozkładu zadłużenia kredytowego w gospodarstwach domowych poszczególnych krajów stre- 
fy euro. Pośrednio problem ten poruszyli Lenza i Slacalek (2018), modelując wpływ APP na zamożność indywidualnych gospodarstw domowych w czterech krajach, mierzoną m.in. wartością aktywów i zobowiązań respondentów. Wyniki potwierdziły umiarkowany wpływ niestandardowych instrumentów polityki pieniężnej na rozkład bogactwa w populacjach. Podobne badanie przeprowadzili Ampudia i in. (2018), analizując wpływ polityki pieniężnej (w szczególności luzowania ilościowego) na nierówność rozkładu dochodów, majątku i konsumpcji w gospodarstwach domowych w krajach strefy euro. Jak stwierdzono, niskie krótkoterminowe stopy procentowe szkodzą w sposób bezpośredni „oszczędzającym” gospodarstwom domowym, ponieważ zmniejszają osiągane przez nie dochody. Tym samym można odnotować, że oddziałują one pozytywnie na sytuację finansową gospodarstw posiadających zadłużenie oprocentowane według stopy zmiennej. Zdaniem autorów polityka pieniężna przyniosła korzyści finansowe większości gospodarstw domowych badanych krajów i nie przyczyniła się do wzrostu zróżnicowania poziomu ich zamożności.

\section{Działania Eurosystemu na rzecz liberalizacji polityki kredytowej}

W okresie kryzysu finansowego restrykcyjna polityka kredytowa banków negatywnie oddziaływała na sytuację gospodarczą krajów strefy euro. Pogarszającej się wówczas kondycji sektorów finansów publicznych i nasilającemu się ryzyku redenominacji towarzyszyła wyraźna segmentacja rynku finansowego, prowadząca do różnicowania dostępności oraz warunków kredytowania dla klientów niefinansowych (w tym gospodarstw domowych) w poszczególnych krajach.

W związku z zaistniałą sytuacją w 2014 r. Rada Prezesów EBC przyjęła pakiet instrumentów, które z jednej strony miały dostarczać płynność instytucjom kredytowym, z drugiej zaś wzmacniać transmisję impulsów polityki pieniężnej, a w konsekwencji - zwiększyć dostępność kredytów i złagodzić warunki ich udzielania, aby ułatwić krajom wejście na ścieżkę wzrostu gospodarczego. Głównymi elementami pakietu były:

- targeted longer-term refinancing operations (TLTROs),

- programy skupu dłużnych papierów wartościowych sektora prywatnego (asset-backed securities purchase programme - ABSPP; covered bond purchase programme 3 - CBPP3; corporate sector purchase programme - CSPP),

- program skupu dłużnych papierów wartościowych sektora publicznego (public sector purchase programme - PSPP),

- ujemna stopa procentowa dla operacji depozytowych Eurosystemu.

TLTRO stanowiły źródło długoterminowego (do 4 lat) finansowania dla instytucji kredytowych, oprocentowanego według stopy stałej i dostarczanego w ramach ośmiu operacji przeprowadzanych co kwartał, począwszy od września 2014 r. Możliwość korzystania z niego była uzależniona od skali działalności kredytowej podmiotów, pro- 
wadzonej na rzecz przedsiębiorstw niefinansowych i gospodarstw domowych. Pierwsza seria operacji (TLTRO I) została ogłoszona 5 czerwca 2014 r., a druga (TLTRO II) 10 marca 2016 r. Należy dodać, że zgodnie z warunkami TLTRO II oprocentowanie funduszy dostarczanych bankom było tym niższe, im większe było ich zaangażowanie w kredytowanie sektora niefinansowego, pomijając jednak kredyty na nieruchomości. Ponadto operacje te umożliwiały bankom pozyskanie długoterminowych pożyczek w wysokości do 30\% salda udzielonych kredytów (ECB, 2017b, s. 42-46).

We wrześniu 2014 r. podjęto decyzję o obniżeniu oprocentowania operacji depozytowych do poziomu $-0,20 \%$. W celu usprawnienia funkcjonowania mechanizmu transmisji impulsów polityki pieniężnej i wsparcia rozwoju kredytowania gospodarek krajów ogłoszono też dwa programy skupu dłużnych papierów wartościowych: CBPP $3^{2}$ oraz ABSPP. ${ }^{3}$ Łącznie z TLTRO przyczyniły się one do obniżenia stóp procentowych rynku pieniężnego i złagodzenia warunków zadłużania się instytucji kredytowych w strefie euro. Należy dodać, że nastąpił wówczas wzrost kredytowania przez banki klientów niefinansowych, lecz wyłącznie w krajach o wysokich ocenach ratingowych. W pozostałych instytucje kredytowe znajdowały się pod presją delewarowania działalności i zmagały się z problemem wysokich odpisów z tytułu utraty wartości aktywów (kredytów).

W styczniu 2015 r. niski poziom inflacji przesądził o wprowadzeniu kolejnego programu $\mathrm{EBC}-\mathrm{PSPP}^{4}$, który wraz z ABSPP i CBPP 3 określono mianem expanded asset purchase programmes (APP). Oprócz wzmocnienia transmisji impulsów polityki pieniężnej jego zadaniem było zwiększenie dostępności funduszy obcych dla podmiotów sektora finansowego i niefinansowego (w tym przez kredyt bankowy), a tym samym oddziaływanie na wzrost gospodarczy i poziom inflacji. Przyjęto miesięczną wartość transakcji przeprowadzanych w ramach APP na poziomie $60 \mathrm{mld}$ euro oraz założono jego kontynuację do września 2016 r. lub do momentu, w którym Rada Prezesów EBC uzna wzrost stopy inflacji za stały.

W grudniu 2015 r. oraz w marcu 2016 r. pakiet środków obejmujący TLTRO, ujemną stopę procentową dla operacji depozytowych oraz APP został odpowiednio skorygowany. Obniżono wówczas stopę depozytową o 10 p.b. do poziomu $-0,3 \%$ oraz wydhużono okres obowiązywania APP o 6 miesięcy (do marca 2017 r.). Ponadto w marcu 2016 r. zwiększono miesięczny limit dla APP do 80 mld euro i dołączono do niego CSPP. ${ }^{5}$ Co ważne, pomimo sygnalizowanej wcześniej poprawy warunków

2 Covered bond purchase programme 3 (CBPP 3) rozpoczęto w dniu 20 października 2014 r. Stanowił on kontynuację programów CBPP 1 i CBPP 2, ukierunkowanych na zakup przez Eurosystem obligacji zabezpieczonych, wyemitowanych przez instytucje kredytowe (ECB, 2014).

3 Asset-backed securities purchase programme (ABSPP) rozpoczęto w dniu 21 listopada $2014 \mathrm{r}$. Umożliwiał on Eurosystemowi zakup asset-backed securities (ABS) na rynkach pierwotnych i wtórnych. Jego dodatkowym celem było ułatwienie instytucjom kredytowym dywersyfikowania źródeł finansowania oraz wspieranie nowych emisji dłużnych papierów wartościowych (ECB, 2015a).

4 Public sector purchase programme (PSPP) wprowadzono w dniu 9 marca 2015 r. Polegał on na skupie dłużnych papierów wartościowych sektora publicznego na rynkach wtórnych (ECB, 2015b).

5 Corporate sector purchase programme (CSPP) wprowadzono w dniu 8 czerwca 2016 r. Dotyczył 
finansowania dla instytucji kredytowych za konieczne uznano przeprowadzenie od czerwca 2016 r. do marca 2017 r. serii czterech ukierunkowanych długoterminowych operacji refinansowych, tj. TLTRO II z 4-letnim terminem zapadalności.

Okres zakupów aktywów netto przez EBC w ramach APP zakończył się w grudniu 2018 r. Pierwsze przedterminowe, dobrowolne spłaty pożyczek zaciągniętych przez instytucje kredytowe w ramach trzech pierwszych operacji TLTRO II możliwe były od czerwca do grudnia $2018 \mathrm{r}$. (w przypadku ostatniej serii rozpoczęły się one w marcu 2019 r.). Tym samym można założyć, iż efekty realizowanej polityki na rzecz ożywienia kredytowania sektora niefinansowego powinny ujawnić się w strefie euro przed końcem $2018 \mathrm{r}$.

\section{Charakterystyka danych i metody badania}

Badanie zróżnicowania krajów strefy euro pod względem kredytowania gospodarstw domowych przez banki w okresie od sierpnia 2007 r. do grudnia $2018 \mathrm{r}$. ukierunkowane było na:

- kształtowanie się należności sektorów instytucji kredytowych z tytułu analizowanych kredytów, w tym ich wolumenu oraz struktury, a także aktywności sektorów w zakresie zawierania nowych umów z gospodarstwami domowymi, z uwzględnieniem wartości oraz rodzaju i poziomu oprocentowania,

- przeciętne znaczenie kredytów dla gospodarstw domowych oraz obciążenie ich rocznych dochodów do dyspozycji spłatą zobowiązań zaciągniętych w instytucjach kredytowych.

Przyjęty okres badania składał się z następujących podokresów:

- utrwalania restrykcyjnej polityki kredytowej w bankach podczas kryzysu płynności, bankowego, zadłużenia publicznego i denominacji (sierpień 2007 r. maj 2014 r.),

- wspomagania przez EBC rozwoju działalności kredytowej banków na rzecz klientów niefinansowych przez stosowanie niestandardowych instrumentów polityki pieniężnej (czerwiec 2014 r. - grudzień 2018 r.).

W badaniu wykorzystano dane liczbowe pochodzące z baz Statistical Data Warehouse EBC i Our Statistics EBC, narodowych banków centralnych oraz z bazy Eurostat Europejskiego Urzędu Statystycznego. Odnosiły się one do poszczególnych krajów strefy euro w zakresie:

- należności sektorów instytucji kredytowych od gospodarstw domowych (w EUR) ogółem oraz z tytułu kredytów: konsumpcyjnych, na nieruchomości i pozostałych $^{6}$,

on zakupu przez Eurosystem dłużnych papierów wartościowych podmiotów gospodarczych (w tym na rynkach wtórnych), aby ułatwić im dostęp do funduszy obcych (ECB, 2016).

6 Należy wyjaśnić, że w statystykach EBC kredyty dla gospodarstw domowych podlegają podzia- 
- oprocentowania nowych kredytów konsumpcyjnych, na nieruchomości oraz pozostałych: rodzaju i przeciętnego poziomu (w \%),

- zobowiązań sektorów gospodarstw domowych z tytułu kredytów per capita (w EUR),

- relacji zobowiązań z tytułu kredytów do rocznych skorygowanych dochodów do dyspozycji sektorów gospodarstw domowych,

- relacji zobowiązań z tytułu nowych kredytów do rocznych skorygowanych dochodów do dyspozycji sektorów gospodarstw domowych.

Analizę porównawczą krajów strefy euro przeprowadzono na podstawie statystyk opisowych odnoszących się do kredytów dla gospodarstw domowych, w tym ich minimalnych, maksymalnych i średnich wartości, oraz zmienności wartości w czasie wyrażonej wariancją i współczynnikiem zmienności. ${ }^{7}$

Ze względu na pozostawanie badania $\mathrm{w}$ fazie eksploracyjnej za ważną uznano identyfikację struktur występujących na rynku kredytów dla gospodarstw domowych strefy euro, pomijając przyczyny ich występowania. W tym celu przeprowadzono analizę skupień z zastosowaniem metody Warda (Pociecha, Podolec, Sokołowski i Zając, 1988, s. 78-84; Grabiński, 1992, s. 101-104). Metoda ta wykorzystuje podejście analizy wariancji do szacowania odległości między skupieniami. Tym samym zmierza do minimalizacji sumy kwadratów odchyleń dwóch skupień, które mogą zostać uformowane na każdym etapie (StatSoft, 2011). Wyniki grupowania krajów strefy euro według ich podobieństwa opisanego określonymi cechami kredytów dla gospodarstw domowych zostały zilustrowane za pomocą dendrogramów z wykorzystaniem tzw. odległości euklidesowej, która jest wyrażona następującym wzorem:

$$
\text { odległość }(x, y)=\left\{\sum_{i}\left(x_{i}-y_{i}\right)^{2}\right\}^{1 / 2}
$$

\section{Charakterystyka kredytów dla gospodarstw domowych w krajach strefy euro}

Niejednolitość krajów pod względem demograficzno-społecznym oraz cech sektorów instytucji kredytowych sprawiła, że sytuacja w zakresie kredytowania gospodarstw domowych pozostawała zróżnicowana w strefie euro w przyjętym okresie badania. Należy zauważyć, że ogólny jej obraz kształtował się przede wszystkim pod wpływem warunków panujących we Francji, w Hiszpanii, Holandii, Niemczech oraz we Włoszech, ponieważ ok. 80\% całkowitej wartości kredytów reprezentowało należności podmiotów z tych krajów (rysunek 1). Analiza skali kredytowania

łowi m.in. ze względu na ich przeznaczenie. Wyróżnia się wówczas kredyty: konsumenckie (finansujące wydatki konsumpcyjne), na nieruchomości, a także pozostałe (głównie na cele związane z prowadzoną działalnością gospodarczą i edukacją).

7 Współczynnik zmienności $\left(v_{s}\right)$ wyraża relacja odchylenia standardowego badanej cechy do jej średniego poziomu w okresie badania (Kończak i Trzpiot, 2004, s. 257). 
w poszczególnych podokresach badania potwierdziła, iż niestandardowym działaniom Eurosystemu na rzecz liberalizacji polityki kredytowej towarzyszył jej wzrost w większości sektorów instytucji kredytowych. Zjawisko to nie zostało jednak potwierdzone dla krajów, które szczególnie silnie odczuły skutki kryzysu finansowego, takich jak Cypr, Grecja, Hiszpania, Irlandia i Portugalia. ${ }^{8}$

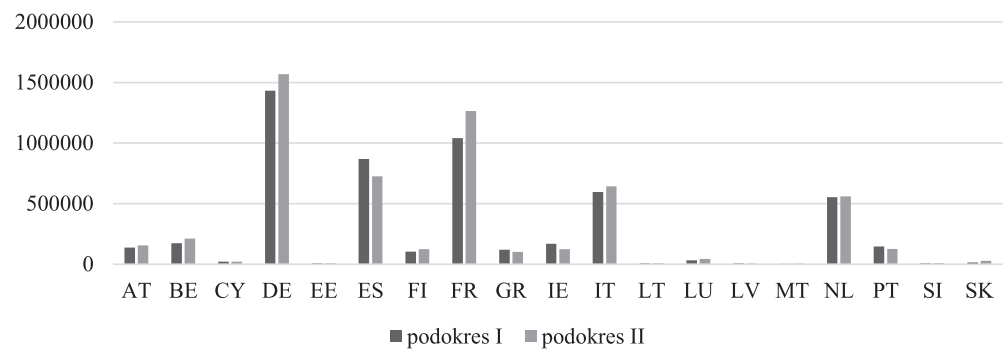

Rysunek 1. Przeciętne wartości należności sektorów instytucji kredytowych od gospodarstw domowych (w mln EUR) w krajach strefy euro w podokresach: (I) sierpień 2007 r. - maj 2014 r. oraz (II) czerwiec 2014 r. - grudzień 2018 r.

Źródło: obliczenia własne na podstawie danych z bazy Euro area statistics (https://www.euro-area-statistics.org/banksbalance-sheet-loans?cr=eur\&lg=en).

Badając strukturę należności instytucji kredytowych od gospodarstw domowych, uwagę zwróciła powszechna dominacja ekspozycji z tytułu kredytów na nieruchomości, których przeciętne udziały kształtowały się w poszczególnych krajach od 50\% do $81 \%$ w podokresie I oraz od $56 \%$ do $85 \%$ w podokresie II (tabela 1 ). Nie można było przy tym wskazać drugiej pod względem ważności kategorii owych należności w strefie euro. W przypadku Francji, Grecji, Portugalii, Słowacji i Słowenii stanowiły ją bowiem kredyty konsumpcyjne, podczas gdy w innych - pozostałe. Uwzględniając preferencje $\mathrm{EBC}$ w zakresie liberalizacji polityki kredytowej, za ważne uznano zidentyfikowanie zmian zachodzących w przeciętnych udziałach kredytów konsumpcyjnych i pozostałych w ogóle kredytów dla gospodarstw domowych. W pierwszym przypadku ich wzrost został potwierdzony jedynie we Włoszech, w Luksemburgu i na Słowacji, stanowiąc efekt obniżenia udziałów kredytów pozostałych, w drugim zaś - w Grecji, w wyniku równoczesnej redukcji udziałów kredytów konsumpcyjnych i na nieruchomości. Warto odnotować, że kredyty na nieruchomości, pozostające poza celem oddziaływania EBC, cechowały wyższe przeciętne udziały w portfelach kredytów dla gospodarstw domowych w podokresie II w aż 13 krajach strefy euro. Największy ich wzrost, wynoszący od 5 p.p. do 11 p.p., wystąpił w sektorach instytucji kredytowych Austrii, Belgii, Cypru, Luksemburga, Malty, Słowenii oraz Słowacji.

8 Dodatkowo problem ten wystąpił na Łotwie. 
Pobrane z czasopisma Annales H - Oeconomia http://oeconomia.annales.umcs.pl Data: 26/04/2023 15:37:37

KREDYTY DLA GOSPODARSTW DOMOWYCH STREFY EURO W OKRESIE RESTRYKCYJNEJ POLITYKI..

Tabela 1. Przeciętne udziały (w \%) kredytów według rodzaju w kredytach ogółem dla gospodarstw domowych w krajach strefy euro w podokresach: (I) sierpień 2007 r. - maj 2014 r. oraz (II) czerwiec 2014 r. - grudzień 2018 r.

\begin{tabular}{|c|c|c|c|c|c|c|c|c|c|c|c|c|c|c|c|c|c|}
\hline Rodzaj & Podokres & AT & $\mathrm{BE}$ & $\mathrm{CY}$ & $\mathrm{DE}$ & ES & FI & FR & GR & IT & LT & $\mathrm{LU}$ & MT & PT & SI & SK & EA \\
\hline \multirow{2}{*}{ Konsumencki } & I & 18 & 8 & 17 & 12 & 10 & 12 & 15 & 27 & 11 & 12 & 6 & 10 & 11 & 32 & 17 & 12 \\
\hline & II & 13 & 6 & 13 & 12 & 10 & 12 & 13 & 24 & 13 & 8 & 7 & 8 & 11 & 24 & 19 & 11 \\
\hline \multirow{2}{*}{ Na nieruchomości } & I & 57 & 78 & 50 & 68 & 76 & 74 & 76 & 64 & 58 & 74 & 58 & 72 & 81 & 50 & 70 & 72 \\
\hline & II & 65 & 85 & 56 & 71 & 76 & 75 & 79 & 62 & 59 & 80 & 66 & 81 & 82 & 62 & 76 & 75 \\
\hline \multirow{2}{*}{ Pozostałe } & I & 26 & 15 & 33 & 19 & 15 & 14 & 8 & 9 & 31 & 14 & 36 & 18 & 9 & 18 & 13 & 16 \\
\hline & II & 23 & 9 & 32 & 17 & 14 & 13 & 7 & 14 & 27 & 12 & 28 & 11 & 7 & 14 & 5 & 14 \\
\hline
\end{tabular}

Źródło: obliczenia własne na podstawie danych z bazy Euro area statistics (https://www.euro-area-statistics.org/banksbalance-sheet-loans?cr=eur\&lg=en).

Jak wskazuje się w literaturze, zróżnicowanie warunków kredytowania gospodarstw domowych w krajach strefy euro wynikało m.in. z niejednolitości stosowanego przez banki oprocentowania, zarówno w odniesieniu do jego rodzaju, jak i poziomu (rysunek 2). Różne rodzaje stóp procentowych były przypisywane m.in. kredytom konsumpcyjnym. $Z$ tego względu w statystykach EBC i narodowych banków centralnych należności instytucji kredytowych z ich tytułu zostały podzielone na następujące podkategorie: o zmiennym lub stałym oprocentowaniu do 1 roku (kons $<1 y$ ); o stałym oprocentowaniu w okresie umownym trwającym dłużej niż rok, lecz do 5 lat (kons 1-5y); o stałym oprocentowaniu przez okres umowny dłuższy niż 5 lat $(k o n s>5 y)$. Pomimo powyższych różnic dla większości krajów potwierdzono niższe przeciętne oprocentowanie kredytów, które zostały udzielone w okresie oddziaływania EBC na politykę kredytową banków. Różnica ta była szczególnie widoczna dla kredytów o stopie stałej w okresie dłuższym niż 5 lat (spadek o 11,2 p.p.) w sektorze instytucji kredytowych Litwy. Analiza warunków panujących na rynku kredytów konsumpcyjnych w strefie euro potwierdziła jednak wzrost zróżnicowania przeciętnych krajowych poziomów oprocentowania dla kons < ly (z 9,4 p.p. do 16,9 p.p.), który był spowodowany przede wszystkim sytuacją na Łotwie w podokresie II. $\mathrm{Z}$ kolei w przypadku pozostałych dwóch podkategorii (kons 1-5y i kons $>5 y$ ) nastąpiło częściowe zniwelowanie różnic w powyższym zakresie na obszarze strefy euro. Należy zauważyć, że rozpiętość przeciętnych poziomów stóp procentowych w ramach określonych podkategorii kredytów informowała o stopniu heterogeniczności krajów współtworzących rynek kredytów i objętych wspólną polityką pieniężną.

Przeciętny poziom oprocentowania dla nowo udzielanych pozostałych kredytów oraz debetów ${ }^{9}$ również okazał się niższy w podokresie II w większości krajów (rysunek 2$)^{10}$, przy czym o jego ograniczonej rozpiętości w strefie euro można było

\footnotetext{
9 Należy odnotować, że statystyki EBC i narodowych banków centralnych dotyczące oprocentowania nowych kredytów traktują debety jako osobną podkategorię kredytów dla gospodarstw domowych.

${ }_{10}$ Wyjątkiem był sektor instytucji kredytowych Łotwy, w którym wzrost przeciętnej stopy procentowej dla debetów wyniósł 11,6 p.p.
} 
wnioskować jedynie w odniesieniu do pozostałych kredytów o stopie zmiennej lub stałej do roku (pozost<1y). Warto też zwrócić uwagę na zwiększoną rozpiętość przeciętnego oprocentowania debetów, która w zbiorowości krajów sięgała w podokresie II aż 17,4 p.p.

Niejednolitość warunków kredytowania gospodarstw domowych w krajach strefy euro dotyczyła także kredytów na nieruchomości (rysunek 2). Zróżnicowanie rodzaju oprocentowania przypisywanego tym kredytom skutkowało wyróżnieniem w statystykach EBC i narodowych banków centralnych następujących ich podkategorii: o zmiennym lub stałym oprocentowaniu w okresie do roku $($ nieruch $<1 y)$; o stałym oprocentowaniu w okresie umownym dłuższym niż rok, lecz do 5 lat (nieruch1-5y); o stałym oprocentowaniu w okresie umownym dłuższym niż 5 lat, lecz nieprzekraczającym 10 lat (nieruch5-10y); o stałym oprocentowaniu w okresie umownym dłuższym niż 10 lat (nieruch $>10 y$ ). W przypadku kredytów oprocentowanych według stopy zmiennej lub stałej do roku heterogeniczność ich warunków w krajach strefy euro, wyrażona rozpiętością przeciętnych poziomów stopy procentowej, uległa zmniejszeniu w podokresie II. Odwrotne wnioski należało natomiast sformułować dla pozostałych podkategorii tych kredytów, a zatem cechujących się stałością oprocentowania w długim okresie (powyżej roku). Odnośnie do podkategorii nieruch1-5y i nieruch5-10y zakres przeciętnych poziomów stóp procentowych uległ podwojeniu w grupie badanych krajów.

Analizując kredytowanie gospodarstw domowych przez instytucje kredytowe w poszczególnych krajach, uwagę zwrócono także na zmienność jego wartości w czasie (tabela 2 ). Na podstawie wartości współczynnika zmienności $\left(v_{s}\right)$ dla podokresów I i II stwierdzono, iż działaniom EBC na rzecz liberalizacji polityki kredytowej towarzyszyła większa stabilność całkowitego poziomu należności sektorów instytucji kredytowych od gospodarstw domowych. ${ }^{11}$ Wniosek ten nie dotyczył jednak Estonii, Litwy i Niemiec. Co ciekawe, w zbiorowości krajów największą zmiennością całkowitej wartości kredytów (niezależnie od podokresu) wyróżnił się sektor Słowacji. Wynikała ona z lokalnych uwarunkowań wszystkich segmentów rynku - kredytów konsumpcyjnych, na nieruchomości oraz pozostałych. Należy dodać, iż badanie pozwoliło zidentyfikować również przypadki podwyższonej zmienności zagregowanych wartości określonych kategorii kredytów w okresie utrwalania restrykcyjnej polityki kredytowej. W Hiszpanii i na Łotwie problem ten dotyczył kredytów konsumpcyjnych, a w Irlandii i na Litwie - kredytów konsumpcyjnych i pozostałych. W Grecji współczynnik $v_{s}$ przekroczył $62 \%$ dla pozostałych kredytów, informując o dużej zmienności ich wartości w czasie.

${ }_{11}$ To samo można wnioskować w odniesieniu do całej zbiorowości krajów strefy euro, dla której współczynnik $v_{s}$ wyniósł w I podokresie $3,4 \%$, natomiast w II - 2,6\%. 
Pobrane z czasopisma Annales H - Oeconomia http://oeconomia.annales.umcs.pl

Data: 26/04/2023 15:37:37

KREDYTY DLA GOSPODARSTW DOMOWYCH STREFY EURO W OKRESIE RESTRYKCYJNEJ POLITYKI... 81

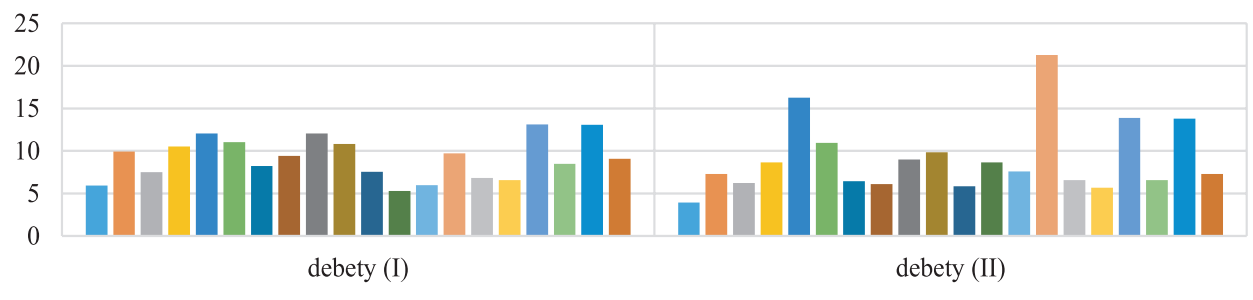

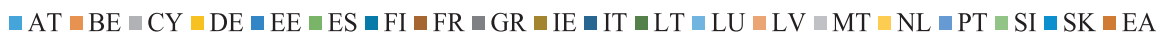

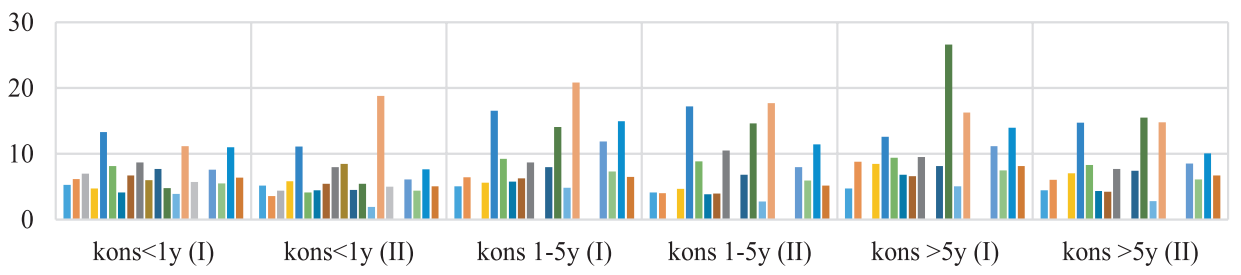

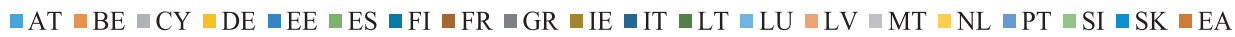

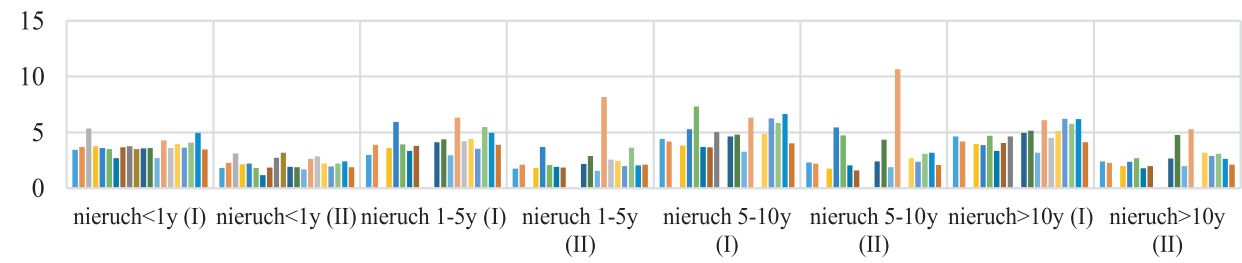

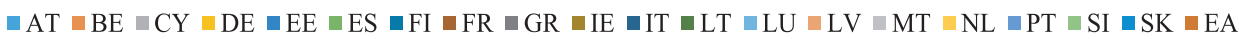

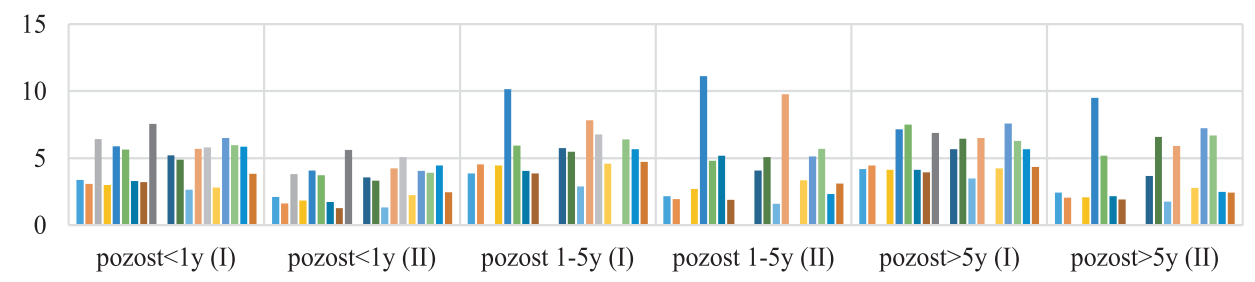

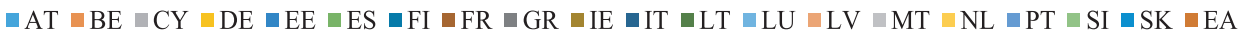

Rysunek 2. Przeciętne oprocentowanie nowych kredytów (w \%, według rodzaju) dla gospodarstw domowych w krajach strefy euro w podokresach: (I) sierpień 2007 r. - maj 2014 r. oraz (II) czerwiec 2014 r. - grudzień 2018 r.

Źródło: opracowanie własne na podstawie danych z bazy Euro area statistics (https://www.euro-area-statistics.org/ bank-interest-rates-loans?cr=eur\&lg=en). 
Tabela 2. Współczynnik zmienności $v_{s}$ (w \%) dla należności sektorów instytucji kredytowych od gospodarstw domowych w krajach strefy euro w podokresach: (I) sierpień 2007 r. - maj 2014 r. oraz (II) czerwiec 2014 r. - grudzień 2018 r.

\begin{tabular}{|c|c|c|c|c|c|c|c|c|c|c|c|c|c|c|c|c|c|c|c|c|}
\hline & & AT & BE & $\mathrm{CY}$ & DE & $\mathrm{EE}$ & ES & FI & FR & GR & IE & IT & LT & LU & LV & MT & NL & PT & SI & SK \\
\hline \multirow[b]{2}{*}{ zółem } & & & 2 & 11,8 & & ,1] & 5,0 & 10,0 & \begin{tabular}{|l|}
8,7 \\
\end{tabular} & 15 & 7,6 & 5,1 & \begin{tabular}{|l|}
6,7 \\
\end{tabular} &, 2 & 1, & 2,7 & 4,5 & & & 1,5 \\
\hline & & & & & & & 2,4 & 3,1 & 5,7 & & 5,4 & 2,7 & 8,7 & & 3,5 & 7,6 & 4 & & & \\
\hline & & & & 14,0 & 3,3 & 14,5 & 20,2 & 4,9 & \begin{tabular}{|l|}
2,2 \\
\end{tabular} & & 25,1 & 6,1 & 23,8 & 12 & 21,1 & 9,1 & 6,3 & & & 3,1 \\
\hline & & 8 & 9 & 10 & 4,3 & 9,9 & 14,9 & 5,3 & \begin{tabular}{|l|}
4,9 \\
\end{tabular} & 8,7 & $\begin{array}{ll}7 & 5,6 \\
\end{array}$ & 17,7 & 4,3 & 14,0 & 5,3 & 5,5 & 10,1 & 10,2 & 9,2 & 15,9 \\
\hline \multirow{2}{*}{$\begin{array}{l}\mathrm{Na} \\
\text { nieruchomości }\end{array}$} & & 9,6 & 12,3 & 18,9 & 2,2 & 2,3 & 3,2 & 11,6 & 10,4 & & 316,6 & 14,3 & 6,6 & 15,8 & 9,8 & 16,2 & 3,4 & & 21,6 & 25,2 \\
\hline & & 6,6 & 11,2 & 6,8 & 5,3 & 7,4 & 4,1 & 2,9 & \begin{tabular}{|l|}
6,3 \\
\end{tabular} & 7,5 & \begin{tabular}{|l|l|}
5 & 2,6 \\
\end{tabular} & 1,9 & \begin{tabular}{|l|}
8,9 \\
\end{tabular} & \begin{tabular}{|l|}
9,0 \\
\end{tabular} & 4,2 & 10,3 & 7,9 & & 4,8 & 16,3 \\
\hline \multirow{2}{*}{ ozostałe } & & 2,7 & 9,3 & 10,1 & 1,7 & 14,3 & 6,4 & 6,0 & \begin{tabular}{|l|}
5,9 \\
\end{tabular} & 62,3 & 320,3 & 9,5 & 20,2 & & 18,1 & \begin{tabular}{|l|}
4,7 \\
\end{tabular} & 13,2 & 7, & 5,2 & 21,4 \\
\hline & & 2,8 & 3,7 & 16,6 & $\begin{array}{ll}1,7 \\
\end{array}$ & \begin{tabular}{|l|}
4,2 \\
\end{tabular} & 4,1 & 2,9 & \begin{tabular}{|l|}
2,6 \\
\end{tabular} & 4,6 & & 6,1 & 13,6 & \begin{tabular}{|l|}
2,7 \\
\end{tabular} & & 5,4 & 4,0 & 10,9 & 4,5 & 5, \\
\hline
\end{tabular}

Źródło: obliczenia własne na podstawie danych z bazy Euro area statistics (https://www.euro-area-statistics.org/banksbalance-sheet-loans?cr=eur\&lg=en).

Warto zauważyć, że kredyty bankowe stanowily dla gospodarstw domowych źródło finansowania dłużnego, którego popularność w poszczególnych krajach pozostawała zróżnicowana. Podobne wnioski można było sformułować odnośnie do obciążenia dochodów gospodarstw spłatą posiadanego przez nie zadłużenia. Analiza należności sektorów instytucji kredytowych od gospodarstw domowych per capita pozwoliła zweryfikować popularność kredytów w krajach o populacjach różnej wielkości, sprowadzając je do porównywalności. Z kolei odniesienie owych należności do rocznych dochodów do dyspozycji sektorów gospodarstw domowych służyło porównaniu obciążeń gospodarstw z tytułu kredytów, eliminując problem dysproporcji w ich sytuacji dochodowej w poszczególnych krajach. W tym wypadku za ważne uznano wykorzystanie zarówno danych na temat całkowitego zadłużenia gospodarstw, jak i wynikającego z nowo udzielanych kredytów.

Jak wykazano w tabeli 3, gospodarstwa domowe poszczególnych krajów w różnym stopniu korzystały z kredytów bankowych. To źródło finansowania okazało się mieć największe znaczenie dla gospodarstw Luksemburga, których przeciętne zadłużenie w bankach sięgało 62791 EUR w podokresie I oraz 74103 EUR w pod-

Tabela 3. Należności sektorów instytucji kredytowych od gospodarstw domowych per capita (w EUR) w krajach strefy euro w podokresach: (I) sierpień 2007 r. - maj 2014 r. oraz (II) czerwiec 2014 r. grudzień $2018 \mathrm{r}$.

\begin{tabular}{|c|c|c|c|c|c|c|c|c|c|c|c|c|c|c|c|c|c|c|c|}
\hline 1 & AT & $\mathrm{BE}$ & $\mathrm{CY}$ & DE & EE & ES & FI & FR & GR & IE & IT & LT & LU & LV & MT & NL & PT & SI & SK \\
\hline I & $\begin{array}{l}\tilde{\vec{J}} \\
\vec{J}\end{array}$ & $\begin{array}{l}\hat{\sigma} \\
\text { } \\
\stackrel{\infty}{n}\end{array}$ & 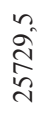 & $\begin{array}{l}0 \\
\pm \\
\pm \\
\text { J }\end{array}$ & 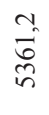 & $\begin{array}{l}+ \\
\infty \\
\infty \\
\infty\end{array}$ & $\begin{array}{l}\hat{\sigma} \\
\text { ஸे } \\
\hat{\sigma}\end{array}$ & 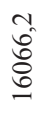 & $\begin{array}{l}\infty \\
\hat{n} \\
\infty \\
0\end{array}$ & $\begin{array}{l}\stackrel{0}{0} \\
\stackrel{m}{N} \\
\frac{\pi}{n}\end{array}$ & 용 & $\begin{array}{l}\tilde{n} \\
\text { ñ } \\
\text { ñ }\end{array}$ & $\frac{\vec{\sigma}}{\hat{\sigma}}$ & $\underset{m}{\vec{f}}$ & $\frac{t_{n}}{\stackrel{\infty}{\circ}}$ & $\begin{array}{l}n \\
\tilde{\delta} \\
\text { m} \\
\tilde{m}\end{array}$ & 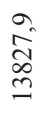 & $\begin{array}{l}\infty \\
\stackrel{\infty}{\sim} \\
\stackrel{\sim}{\sim}\end{array}$ & $\begin{array}{l}\text { } \\
\infty \\
\infty \\
\infty\end{array}$ \\
\hline II & 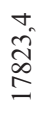 & $\begin{array}{l}n \\
\stackrel{2}{\curvearrowright} \\
\infty\end{array}$ & 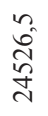 & $\frac{\sqrt{n}}{a}$ & $\begin{array}{l}0 \\
\frac{0}{n} \\
\infty \\
n\end{array}$ & $\begin{array}{l}\tilde{\sigma} \\
\tilde{n}\end{array}$ & \begin{tabular}{l}
$n$ \\
\multirow{J}{*}{} \\
N
\end{tabular} & ๙̊. & 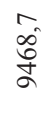 & 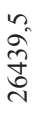 & 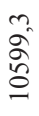 & 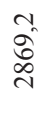 & 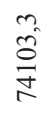 & $\frac{\stackrel{0}{J}}{\stackrel{\Delta}{N}}$ & $\begin{array}{l}\stackrel{m}{n} \\
\stackrel{\tilde{y}}{=}\end{array}$ & $\begin{array}{l}\vec{\delta} \\
\text { } \\
\text { సે }\end{array}$ & $\stackrel{\infty}{\stackrel{\infty}{\circ}}$ & $\begin{array}{l}\text { â } \\
\text { ğ }\end{array}$ & $\begin{array}{l}\infty \\
\infty \\
\infty \\
\text { N } \\
\text { n. }\end{array}$ \\
\hline
\end{tabular}

Źródło: obliczenia własne na podstawie danych z baz Euro area statistics (https://www.euro-area-statistics.org/banksbalance-sheet-loans?cr=eur\&lg=en) oraz Eurostat (https://ec.europa.eu/eurostat/web/population-demography-migrationprojections/data/database). 
okresie II. W znacznym stopniu korzystano z niego także na Cyprze, w Irlandii i Holandii, ponieważ średnia wartość kredytów przypadająca na mieszkańca przewyższała tam 20000 EUR w obu podokresach. Najmniej zależne od tej formy finansowania okazały się gospodarstwa domowe Litwy oraz Łotwy, których przeciętne zadłużenie kształtowało się na poziomie bliskim 3000 EUR.

Największe dysproporcje w obciążeniu dochodów zaciągniętymi kredytami zidentyfikowano pomiędzy Holandią i Słowenią, w których zadłużenie sektorów gospodarstw domowych stanowiło odpowiednio ponad 200-krotność i 45-krotność ich rocznych dochodów do dyspozycji (tabela 4). Należy zauważyć, że w okresie prowadzenia przez EBC działań na rzecz liberalizacji polityki kredytowej większy ciężar spłaty długów zaobserwowano jedynie w części krajów strefy euro.

Tabela 4. Przeciętne wartości wskaźnika zobowiązania z tytułu kredytów / skorygowany dochód do dyspozycji w sektorach gospodarstw domowych wybranych krajów strefy euro* w podokresach:

(I) sierpień 2007 r. - maj 2014 r. oraz (II) czerwiec 2014 r. - grudzień 2018 r.

\begin{tabular}{|c|c|c|c|c|c|c|c|c|c|c|c|c|}
\hline & AT & BE & DE & ES & FI & FR & GR & IE & IT & NL & PT & SI \\
\hline I & 84,0 & 87,2 & 87,2 & 128,2 & 103,0 & 81,4 & 82,5 & 201,6 & 61,2 & 219,4 & 125,2 & 45,4 \\
\hline II & 84,6 & 102,5 & 82,5 & 105,2 & 113,1 & 90,7 & 91,0 & 148,0 & 61,4 & 204,2 & 107,6 & 45,1 \\
\hline
\end{tabular}

* brak w bazie EBC wartości wskaźnika dla części krajów strefy euro

Źródło: obliczenia własne na podstawie danych EBC (https://sdw.ecb.europa.eu/reports.do?node=1000004963).

Ocena obciążenia dochodów do dyspozycji sektorów gospodarstw domowych spłatą nowo zaciąganych kredytów możliwa była tylko na podstawie danych rocznych (tabela 5). Z tego powodu za podokres I przyjęto lata 2008-2013, a za podokres II - lata 2014-2017. ${ }^{12}$ Należy dodać, że przyjęty wskaźnik nawiązuje do pojęcia zdolności kredytowej, postrzegającej dochody gospodarstw jako podstawowe źródło spłaty kredytów. Tym samym posłużył on do identyfikacji różnic w polityce kredytowej prowadzonej przez banki w poszczególnych krajach. Najbardziej restrykcyjne podejście do udzielania nowych kredytów cechowało sektory instytucji kredytowych Hiszpanii, Irlandii i Portugalii, dla których wartości wskaźnika informowały o nadwyżce spłacanych kredytów nad nowo zaciąganymi przez gospodarstwa w obu podokresach. Natomiast w przypadku Austrii, Niemiec, Francji, Estonii i Słowacji wyższa wartość wskaźnika w podokresie II pozwoliła wnioskować o liberalizacji polityki kredytowej. Najmniej restrykcyjną polityką kredytową w strefie euro w obu podokresach wyróżniły się sektory Belgii, Finlandii i Słowacji, w których nowo udzielane kredyty stanowiły przeciętnie 4-krotność lub 5-krotność rocznych dochodów do dyspozycji sektorów gospodarstw domowych.

${ }^{12}$ Brak danych kwartalnych. Ostatnia raportowana wartość wskaźnika dotyczyła 2017 r. 
Pobrane z czasopisma Annales H - Oeconomia http://oeconomia.annales.umcs.pl

Data: 26/04/2023 15:37:37

84

KATARZYNA KOCHANIAK

Tabela 5. Przeciętne wartości wskaźnika nowe zobowiązania z tytułu kredytów / skorygowany dochód do dyspozycji dla sektorów gospodarstw domowych wybranych krajów strefy euro i całej ich grupy

w podokresach: (I) wrzesień 2007 r. - czerwiec 2014 r. oraz (II) lipiec 2014 r. - grudzień 2018 r.

\begin{tabular}{|c|c|c|c|c|c|c|c|c|c|c|c|c|c|}
\hline & AT & BE & DE & ES & EE & FI & FR & IE & NL & PT & SI & SK & EA \\
\hline I & 0,8 & 4,3 & 0,2 & $-1,5$ & $-0,2$ & 5,2 & 3,2 & $-1,6$ & 4,1 & $-0,7$ & 1,3 & 5,4 & 1,3 \\
\hline II & 1,5 & 4,3 & 2,0 & $-2,3$ & 3,7 & 4,0 & 3,3 & $-4,1$ & 1,3 & $-1,9$ & 1,1 & 5,9 & 1,5 \\
\hline
\end{tabular}

Źródło: obliczenia własne na podstawie danych EBC (https://sdw.ecb.europa.eu/reports.do?node=1000004963).

\section{Wyniki grupowania krajów strefy euro ze względu na podobieństwo cech kredytów dla gospodarstw domowych}

W sytuacji zróżnicowania krajów strefy euro pod względem dostępności i warunków kredytowania gospodarstw domowych za ważne uznano zidentyfikowanie względnie jednolitych ich podzbiorów w obu podokresach. Należy wyjaśnić, że wyniki otrzymane dla podokresu I potraktowano jako wyjściowe w ocenie warunków panujących w podokresie II. Podejście to pozwoliło wnioskować o trwałości podobieństw krajów w zakresie kształtowania kredytów w zmiennym otoczeniu sektorów instytucji kredytowych i sektorów gospodarstw domowych, a w szczególności w okresie instytucjonalnego oddziaływania na ich wzajemne relacje.

Grupowanie krajów zostało przeprowadzone metodą Warda na podstawie danych liczbowych odnoszących się do kształtowania całkowitych należności sektorów instytucji kredytowych od gospodarstw domowych oraz tych wynikających z udzielonych kredytów konsumpcyjnych i pozostałych.

W pierwszym przypadku badanie przeprowadzono dla 15 krajów strefy euro (Austrii, Belgii, Cypru, Finlandii, Francji, Grecji, Hiszpanii, Litwy, Luksemburga, Malty, Niemiec i Portugalii, Słowacji, Słowenii oraz Włoch) ze względu na brak danych liczbowych dla Estonii, Holandii, Irlandii i Łotwy (rysunek 3). Wprowadzono do niego informacje o zmienności $\left(v_{s}\right)$ i przeciętnym poziomie należności sektorów instytucji kredytowych w podokresach I i II. Otrzymane wyniki potwierdziły utrzymujące się podobieństwo krajów pod względem ogólnego kredytowania gospodarstw domowych w ramach podzbiorów tworzonych przez: 1) Austrię, Belgię, Finlandię, Grecję i Portugalię, 2) Cypr, Litwę, Luksemburg, Maltę, Słowację i Słowenię.

Warto zauważyć, że podzbioru nie utworzyły kraje wyróżniające się największymi udziałami w całkowitej wartości kredytów dla gospodarstw domowych w strefie euro: Francja, Hiszpania, Niemcy i Włochy. Wynikało to przede wszystkim z indywidualnego przebiegu zmian w poziomie analizowanych należności sektorów instytucji kredytowych w obu rozpatrywanych podokresach.

W dalszej kolejności uwagę skierowano na krajowe uwarunkowania w zakresie kształtowania się wybranych rodzajów kredytów dla gospodarstw domowych - konsumpcyjnych i pozostałych, których rozwój został uznany przez EBC za priorytetowy. W tej części badania wykorzystano informacje na temat zmienności (wyrażonej wariancją) stopy wzrostu i oprocentowania wskazanych kategorii kredytów, a także 


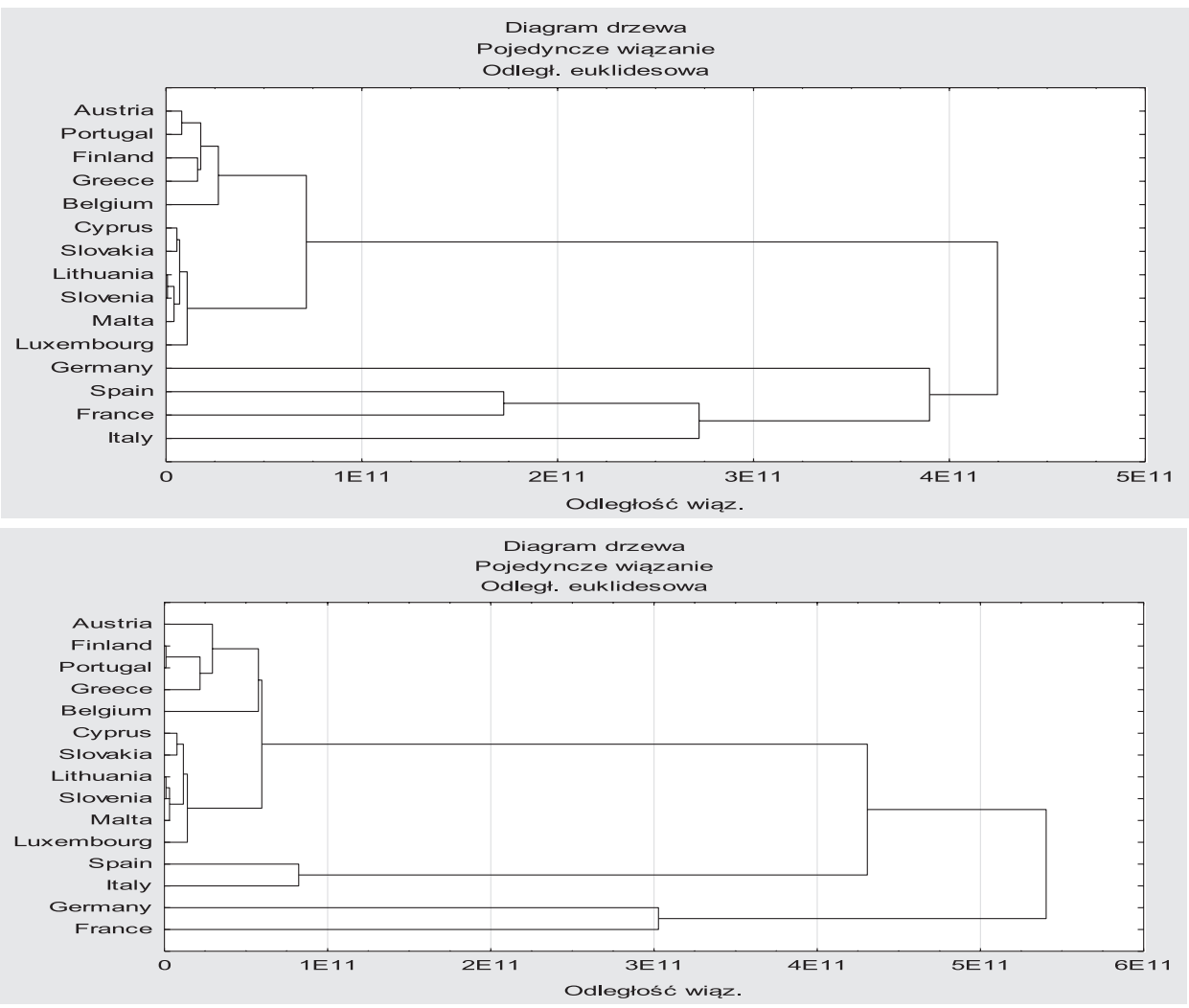

Rysunek 3. Grupowanie krajów metodą Warda ze względu na podobieństwo wybranych cech rynku kredytów dla gospodarstw domowych w podokresach: (I) sierpień 2007 r. - maj 2014 r. oraz (II) czerwiec 2014 r. - grudzień 2018 r.

Źródło: obliczenia własne na podstawie danych z bazy Euro area statistics (https://www.euro-area-statistics.org/banksbalance-sheet-loans?cr=eur\&lg=en).

przeciętnego ich udziału w ogólnej wartości kredytów dla gospodarstw domowych w każdym z podokresów. ${ }^{13}$ Należy podkreślić, że pominięto skalę kredytowania gospodarstw w poszczególnych krajach, ponieważ zależała ona w znacznym stopniu od wielkości populacji. Otrzymane wyniki ukazały istotne różnice w kształtowaniu się sytuacji w wybranych segmentach rynku kredytów nie tylko pomiędzy krajami, lecz również w przyjętych podokresach badania. Wyniki grupowania dla podokresu I najczęściej nie znajdowały potwierdzenia w wynikach dla podokresu II.

W przypadku kredytów konsumpcyjnych (rysunek 4) podobieństwo w zakresie ich kształtowania zostało zidentyfikowane w podokresie I w następujących podzbiorach krajów: (I) Austria, Cypr i Słowacja, (II) Finlandia i Niemcy, (III) Hiszpania,

13 Należy wyjaśnić, że ze względu na brak danych dla Estonii, Holandii, Irlandii i Łotwy kraje te zostały pominięte w tej części badania. 
Malta, Portugalia i Włochy. Poza podzbiorami znalazły się wówczas: Belgia, Francja, Grecja, Litwa, Luksemburg i Słowenia, w których analizowane cechy kształtowały się w sposób zindywidualizowany. Powtórzenie badania dla podokresu II pozwoliło wyłonić takie podzbiory, jak: (I) Austria, Cypr, Francja i Włochy, (II) Finlandia i Niemcy, (III) Litwa i Malta, (IV) Grecja i Słowenia. Poza nimi znalazły się Belgia, Hiszpania, Luksemburg, Portugalia i Słowacja. Ujęcie w badaniu informacji na temat ogółu kredytów konsumpcyjnych w strefie euro posłużyło do weryfikacji podobieństwa ich cech z cechami kredytów występującymi lokalnie (na poziomie krajowym). Ten uogólniony obraz okazał się zbliżony jedynie do sytuacji panującej w Niemczech i Finlandii w obu podokresach badania. Odmienność uwarunkowań pozostałych krajów skłoniła do wnioskowania o ograniczonej przydatności ogólnych informacji o kształtowaniu się kredytów konsumpcyjnych w strefie euro dla podejmowania decyzji i prowadzenia interwencyjnych działań przez EBC. Ponadto podała ona w wątpliwość homogeniczność znaczenia niestandardowych instrumentów polityki pieniężnej Eurosystemu dla kształtowania polityki kredytowej sektorów instytucji kredytowych w poszczególnych krajach.

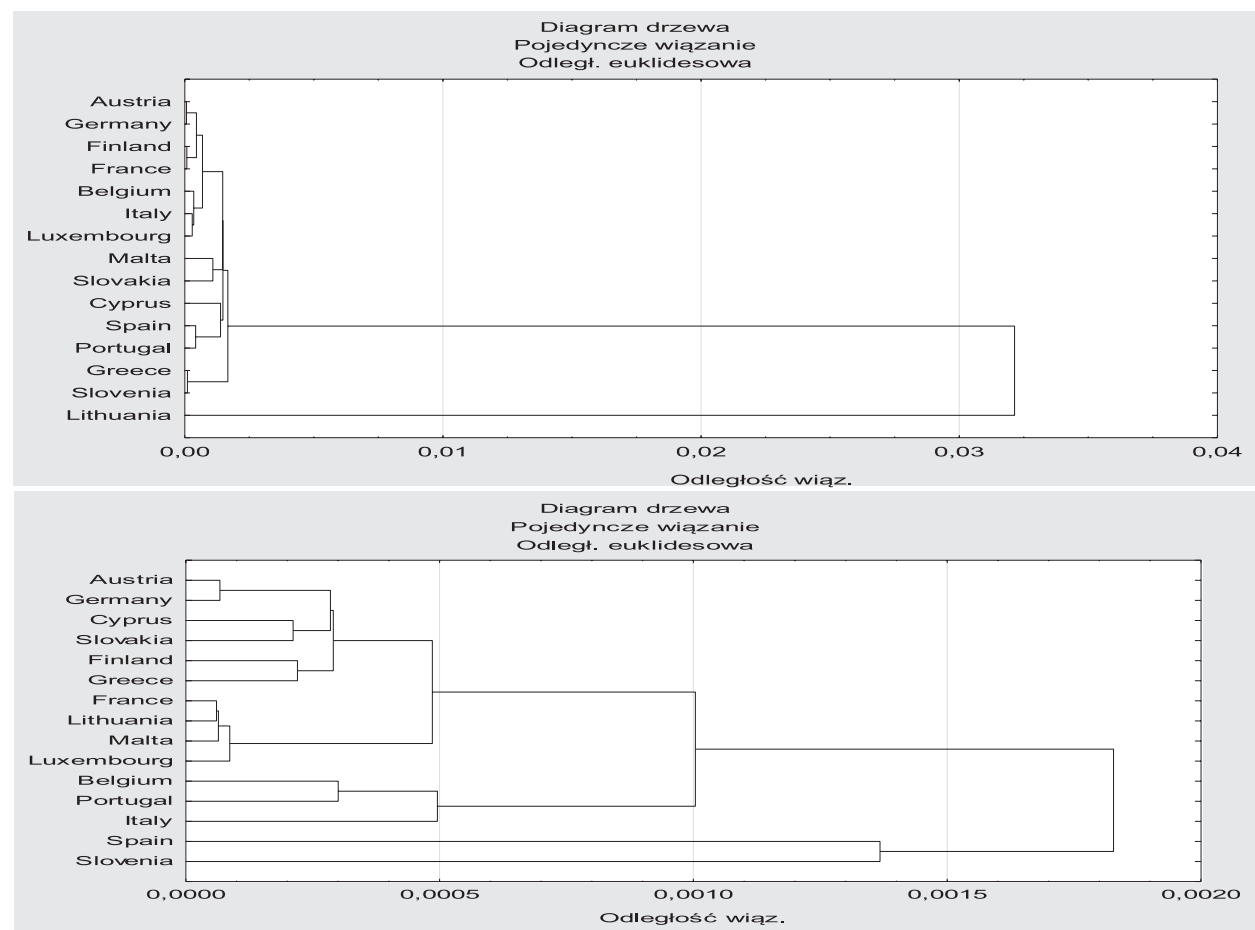

Rysunek 4. Grupowanie krajów metodą Warda ze względu na wybrane cechy rynku kredytów konsumpcyjnych w podokresach: (I) sierpień 2007 r. - maj 2014 r. oraz (II) czerwiec 2014 r. - grudzień 2018 r.

Źródło: obliczenia własne na podstawie danych z bazy Euro area statistics (https://www.euro-area-statistics.org/banksbalance-sheet-loans?cr=eur\&lg=en; https://www.euro-area-statistics.org/bank-interest-rates-loans?cr=eur\&lg=en). 
Otrzymane wyniki wskazały zatem na niestabilność kierunków i natężenia zmian zachodzących w kredytach konsumenckich w krajach strefy euro w podokresach utrwalania restrykcyjnej polityki kredytowej oraz prowadzenia przez EBC działań na rzecz jej liberalizacji. O trwałym podobieństwie warunków, niezależnych od polityki kredytowej sektorów instytucji kredytowych, można było wnioskować jedynie w odniesieniu do Austrii i Cypru, a także Finlandii i Niemiec.

Analiza kształtowania się pozostałych kredytów (rysunek 5) dla gospodarstw domowych (innych niż konsumpcyjne i na nieruchomości) w krajach strefy euro w podokresie I potwierdziła ich podobieństwo w ramach podzbiorów składających się z: (I) Belgii, Finlandii, Hiszpanii i Słowacji, (II) Malty, Niemiec i Słowenii, (III) Francji, Grecji i Portugalii. Tym samym poza nimi znalazły się Austria, Cypr, Litwa, Luksemburg i Włochy. Z kolei w podokresie II podobieństwo owych cech zidentyfikowano pomiędzy: (I) Luksemburgiem i Włochami, (II) Belgią, Francją i Portugalią, (III) Finlandią, Grecją, Hiszpanią, Litwą, Maltą i Słowenią. Podzbiorów nie współtworzyły zatem Austria, Cypr, Niemcy i Słowacja. Podobnie jak w przypadku kredytów konsumpcyjnych wprowadzenie do badania uogólnionych charakterystyk pozostałych kredytów w skali strefy euro pozwoliło wnioskować o ich podobieństwie do cech występujących lokalnie tylko w Finlandii i Hiszpanii w obu podokresach badania.

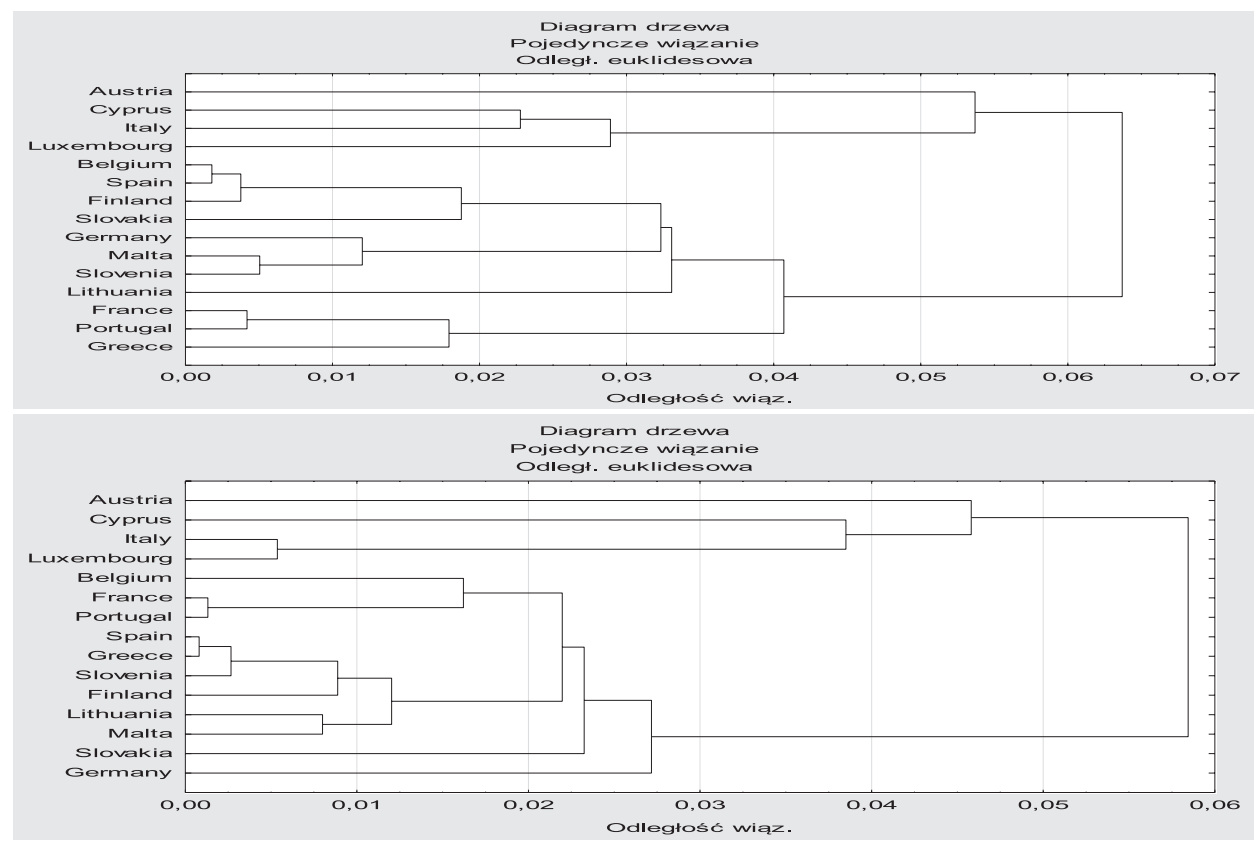

Rysunek 5. Grupowanie krajów metodą Warda ze względu na wybrane cechy rynku pozostałych kredytów w podokresach: (I) sierpień 2007 r. - maj 2014 r. oraz (II) czerwiec 2014 r. - grudzień 2018 r.

Źródło: obliczenia własne na podstawie danych z bazy Euro area statistics (https://www.euro-area-statistics.org/banksbalance-sheet-loans?cr=eur\&lg=en). 
Otrzymane wyniki potwierdziły spójność zmian zachodzących w pozostałych kredytach dla gospodarstw domowych we Francji i w Portugalii, niezależnie od sposobu kształtowania polityki kredytowej. Ponadto podobieństwo warunków w tym segmencie rynku zidentyfikowano pomiędzy Finlandią i Hiszpanią oraz Maltą i Słowenią, które jednak tworzyły dwa odrębne podzbiory w podokresie I. Można więc stwierdzić, że dopiero w podokresie II cztery wskazane kraje charakteryzowały się zgodnością kierunków i intensywnością zmian w zakresie kształtowania pozostałych kredytów dla gospodarstw domowych. Warto dodać, że w całym okresie badania odrębność pod tym względem zachowały Austria i Cypr.

\section{Zakończenie}

W okresie badania restrykcyjna polityka kredytowa banków stanowiła powszechny problem krajów strefy euro, negatywnie oddziałujący na kondycję ich gospodarek. Poprawę dostępności kredytów dla klientów niefinansowych (w tym dla gospodarstw domowych) miały przynieść niestandardowe działania EBC oparte na wybranych instrumentach polityki pieniężnej. Należy podkreślić, iż w zbiorowości krajów strefy euro kredytowanie gospodarstw domowych było zróżnicowane m.in. pod względem przeciętnej wartości i struktury należności sektorów instytucji kredytowych od gospodarstw domowych, przeciętnego poziomu i rodzaju stosowanego oprocentowania, jak również znaczenia tej formy finansowania dla gospodarstw domowych i obciążenia ich dochodów spłacanymi ratami. Pomimo wskazanych różnic można było zaobserwować zgodność kierunków zmian zachodzących w powyższych zakresach w większości krajów w okresie bezpośrednich działań EBC na rzecz kredytowania klientów niefinansowych.

Wyniki przeprowadzonego badania potwierdziły znaczące różnice w skali kredytowania gospodarstw domowych przez instytucje kredytowe na poziomie krajów strefy euro. Największe należności z tego tytułu posiadały podmioty we Francji, w Hiszpanii, Holandii, Niemczech oraz we Włoszech. Należy odnotować, że w okresie aktywizacji działań Eurosystemu w większości państw ich poziomy okazały się mniej podatne na zmiany i średnio wyższe niż w okresie utrwalania restrykcyjnej polityki kredytowej. Obserwowany wówczas rozwój działalności kredytowej na rzecz gospodarstw domowych jednak nie odpowiadał oczekiwaniom EBC, ponieważ w większości przypadków wiązał się ze wzrostem udziału kredytów na nieruchomości w ogólnej wartości kredytów przy ograniczaniu aktywności banków w zakresie udzielania kredytów konsumpcyjnych i pozostałych. Należy dodać, że wskazane zmiany wystąpiły pomimo przypisywania niższego oprocentowania nowym kredytom preferowanym przez EBC.

Problem geograficznego zróżnicowania przeciętnego poziomu oprocentowania nowo udzielanych kredytów w poszczególnych krajach okazał się złożony, gdyż w przypadku niektórych ich podkategorii odnotowano jego obniżenie, podczas gdy 
w innych - wzrost. O ograniczeniu heterogeniczności lokalnych uwarunkowań rynku kredytów można było wnioskować w odniesieniu do kredytów konsumpcyjnych ze stałą stopą procentową w długim okresie oraz kredytów pozostałych i na nieruchomości oprocentowanych według stopy zmiennej lub krótkookresowo stałej (do roku). Z kolei nasilenie owej heterogeniczności dotyczyło kredytów konsumpcyjnych o stopie zmiennej lub stałej w krótkim okresie, debetów oraz kredytów na nieruchomości i pozostałych ze stałą stopą w długim okresie.

Znaczenie kredytów jako źródła zewnętrznego finansowania sektorów gospodarstw domowych również pozostawało zróżnicowane w poszczególnych krajach. Największe dysproporcje w przeciętnym zadłużeniu gospodarstw sięgały bowiem 60 000-70 000 EUR, w zależności od podokresu. Podobne wnioski dotyczą przeciętnego obciążenia rocznych dochodów gospodarstw spłatą ich zadłużenia, zarówno całkowitego, jak i nowo powstałego.

Wyniki grupowania krajów potwierdziły trwałość (niezależnie od podokresu) podobieństwa wybranych krajów pod względem skali kredytowania gospodarstw domowych przez instytucje kredytowe oraz jej zmienności. W przypadku określonych kategorii kredytów (konsumpcyjnych i pozostałych) pominięcie skali kredytowania i skoncentrowanie uwagi na zachodzących w nich zmianach oraz udziale w kredytach ogółem dla gospodarstw domowych prowadziło przede wszystkim do identyfikacji odrębnych podzbiorów krajów dla każdego z podokresów. O trwałym podobieństwie kształtowania kredytów konsumpcyjnych można było wnioskować jedynie w odniesieniu do dwóch par krajów, a w przypadku pozostałych kredytów - trzech par. Ponadto zidentyfikowano kraje cechujące się odrębnością w zakresie rozwoju kredytowania w okresie badania.

\section{Bibliografia}

Ampudia, M., Georgarakos, D., Slacalek, J., Tristani, O., Vermeulen, P., Violante, G.L. (2018). Monetary policy and household inequality. ECB Working Paper Series, (2170).

Black, L.K., Rosen, R.J. (2016). Monetary Policy, Loan Maturity, and Credit Availability. International Journal of Central Banking, 12.

ECB (2014). Decision of the European Central Bank of 15 October 2014 on the implementation of the third covered bond purchase programme (ECB/2014/40) (OJ EU L 335, 22.11.2014).

ECB (2015a). Decision (EU) 2015/5 of the European Central Bank of 19 November 2014 on the implementation of the asset-backed securities purchase programme (OJ EU L 1, 6.1.2015).

ECB (2015b). Decision (EU) 2015/774 of the European Central Bank of 4 March 2015 on a secondary markets public sector asset purchase programme (OJ EU L 121, 14.5.2015).

ECB, (2016). Decision (EU) 2016/948 of the European Central Bank of 1 June 2016 on the implementation of the corporate sector purchase programme (OJ EU L 157, 15.6.2016).

ECB (2017a). MFI lending rates: pass-through in the time of non-standard monetary policy. Pobrane z: https:/www.ecb.europa.eu/pub/pdf/other/eb201701_article01.en.pdf

ECB (2017b). The targeted longer-term refinancing operations: an overview of the take-up and their impact on bank intermediation. ECB Economic Bulletin, (3). 
Pobrane z czasopisma Annales H - Oeconomia http://oeconomia.annales.umcs.pl

Data: 26/04/2023 15:37:37

Gambacorta, L., Marques-Ibanez, D. (2011). The bank lending channel: Lessons from the crisis. BIS Working Papers, (345).

Gambetti, L., Musso, A. (2017). The macroeconomic impact of the ECB's expanded asset purchase programme (APP). ECB Working Paper Series, (2075).

Grabiński, T. (1992). Metody taksonometrii. Kraków: Akademia Ekonomiczna w Krakowie.

Heider, F., Saidi, F., Schepens, G. (2018). Life below zero: bank lending under negative policy rate. ECB Working Paper Series, (2173).

Kończak, G., Trzpiot, G. (2004). Metody statystyczne z wykorzystaniem programów komputerowych. Katowice: Wydawnictwo Akademii Ekonomicznej w Katowicach.

Lenza, M., Slacalek, J. (2018). How does monetary policy affect income and wealth inequality? Evidence from quantitative easing in the euro area. ECB Working Paper Series, (2190).

Pociecha, J., Podolec, B., Sokołowski, A., Zając, K. (1988). Metody taksonomiczne w badaniach społeczno-ekonomicznych. Warszawa: PWN.

StatSoft (2011). Electronic Statistics Textbook. Pobrane z: https://www.statsoft.pl/textbook/stathome_stat. html?https\%3A\%2F\%2Fwww.statsoft.pl\%2Ftextbook\%2Fstcluan.html 